UDC 33.338.482 (061.1

JEL Classification: Z32

DOI: $10.15587 / 2312-8372.2018 .146336$

\section{Sclyarenko Ya., Khanova E.}

\title{
ANALYSIS OF FACTORS OF INFLUENCE ON THE DEVELOPMENT OF TOURISM SPACE OF THE EUROPEAN UNION
}

Об’єктом дослідження є туристичний простір крайн Європейського Союзу (ЄС). Одним з найбільш проблемних місць є значна територіальна різноманітність європейського туристичного простору, що проявляється різним рівнем розвитку туристичної індустрї.

Проведено сегментацію європейсъкого простору за рівнем розвитку туристичної індустрії за допомогою кластерної моделі та виокремлено 7 кластерів країн ЄС за рівнем розвитку туристичної індустрії. Зроблено висновок, що стосовно ієрархї субіндексов, найбільше значення в процесі сегментацї країн СС за рівнем розвитку туристичної індустрії має ресурсна складова та відповідно субіндекс «Природні та культурні ресурси». Субіндекси «Державна політика та створення сприятливих умов у сфері подорожей та туризму» та «Інфраструктура» мають приблизно однакове значення для сегментації країн СС за рівнем розвитку туристичної індустрії. Найменше значення в процесі сегментацї̈ займає субіндекс сприятливості середовища.

У ході дослідження проведено факторний аналіз для визначення вагомих факторів розвитку туристичної індустрї для кожного сегменту (кластеру) для подальшого формування основних аспектів туристичної політики. Зроблено висновок щодо значної вагомості сприятливості середовища для таких країн, як: Австрія, Гречія, Данія, Португалія, Фінляндія, Швеція, Естонія, Латвія, Литва. Розвиток державної політики та створення сприятливих умовах у сфері подорожей та туризму особливо важливо для таких країн, як: Австрія, Греція, Данія, Португалія, Фінляндія, Швеція, Велика Британія, Нідерланди, Франція. Розвиток інфраструктури є вагомим фактором розвитку всіх країн європейського туристичного простору, однак, найбільший вплив має для таких країн, як: Велика Британія, Нідерланди, Франція, Іспанія, Італія, Німеччина, Іспанія, Італія, Кіпр, Мальта. Ресурсна складова розвитку туристичної індустрї̈ найбільш впливає на розвиток туристичної індустрії таких країн, як: Іспанія, Італія, Німеччина, Ірландія, Люксембург.

Завдяки цьому забезпечується можливість сегментувати європейський туристичний конкурентний простір з подальшим удосконаленням туристичної політики Свропейського Союзу.

ключові слова: європейський туристичний простір, конкурентоспроможність туристичної індустрії, сегментація туристичного простору, фактори впливу.

\section{Introduction}

In the context of the globalization of the world economy, the rapid development of the services market, international communications, tourism has become a common practice of lobbying economic, investment, cultural, political and other interests of the state, has become an effective factor in the commodification of recreational resources of the territories. In such conditions, an objective need arises for purposeful influence on the processes of development of the tourism sector, embodied in the peculiarities of the formation and implementation of the tourism policy of countries. From its effectiveness depends on the transformation of tourism into an effective factor of socio-economic development and the formation of the investment attractiveness of the country. Despite this, research into the scientific base of the tourism policy of the state, identifying methods for its implementation in the context of global competition, the main trends in the segmentation of the tourism space and development priorities, evaluating the effectiveness is an actual scientific and practical task.

\section{The object of research and its technological audit}

The object of research is the tourist space of the European Union (EU). A significant number of countries in the Euro- pean Union have a different level of economic development, natural diversity and imbalances in the development of the tourism industry. The study allows to assess the competitiveness in the tourism industry of the EU countries and to identify the obstacles that hinder the sustainable development of the sphere.

\section{The aim and objectives of research}

The aim of research is identification of factors influencing the development of the tourist space of the EU countries. In accordance with the purpose, the following tasks are formulated:

1. To carry out segmentation of the tourist competitive space of the EU and highlight groups (clusters) of countries with a high degree of similarity in the competitiveness of the tourism industry.

2. To determine the main factors influencing the growth and competitiveness of the tourism industry in the EU.

\section{Research of existing solutions of the problem}

The study of the tourism industry is very promising, but the work of researchers is focused: mainly on the theoretical aspects of the formation of tourism policy in 
general [1] or on the purely geographical aspect of the study [2].

In $[3,4]$, the authors thoroughly prove the influence of political stability on the development of tourism, however, the political factor is a significant aspect of the functioning of the tourism industry, but not the main one.

The authors of the studies [5, 6] devote their work to the sustainable development of tourism, but their findings are not supported by a sufficient amount of factual material.

The study of the functioning of the tourist region on the example of Cuba [7] is interesting, however, the experience of a particular country is not enough to analyze a tourist region, such as the European Union. Also interesting are studies on the economic instruments for the development of the tourism industry [8, 9], however, the significant territorial differentiation of the European tourist space requires a significant variety of instruments of influence and development of the tourism industry.

In [10], the author relies in calculations on outdated statistics and their insufficient diversity, which needs to be improved.

Based on literary analysis, it is possible to conclude that previous studies on the topics chosen by the authors, based on the analysis of only a few indicators. And also do not take into account most indicators of tourism competitiveness and almost do not use the methods of economic and mathematical analysis in regional studies of the tourism industry.

\section{Methods of research}

In addition to a significant number of general scientific methods, methods of economic and mathematical analysis are used, namely:

- correlation analysis, which allowed to determine the relationship between the Travel Competitiveness Index and its main components (favorable environment in the country for the development of tourism, government policy, infrastructure and available natural and cultural resources);

- cluster analysis, with the help of which the EU countries (28) are segmented into typical groups (clusters) according to the level of competitiveness of the tourism industry;

- factor analysis, which enabled the 90 components of the competitiveness of the tourism industry to identify the most significant factors in the development of the industry.

\section{Research results}

To determine the factors influencing the development of the EU tourist space, it is first necessary to segmentation of the European space according to the level of development of the tourism industry, applying the cluster model, which clearly forms the segments of coun- tries that have a lot in common according to certain characteristics.

For the analysis, the data of the World Economic Forum, namely, the ranking of countries in the world by the Travel Competitiveness Index 2017 [11] are used.

The study is published every two years and is conducted in close cooperation with a number of leading international organizations:

- World Tourism Organization (UNWTO);

- World Travel and Tourism Council (WTTC);

- International Air Transport Association (IATA);

- The International Union for Conservation of $\mathrm{Na}^{-}$ ture (IUCN) and others.

Travel Competitiveness Index is based on a number of indicators, which are grouped into 14 components and combined into 4 sub-indexes. They characterize the favorable environment in the country for the development of tourism, state policy, infrastructure and the available natural and cultural resources.

According to experts of the World Tourism Organization, the global tourism market has been growing for many years and continues to demonstrate sustainability, despite the difficulties that are primarily related to security.

Each of the constituent sub-indices has a certain agreed list of components, which will be used for cluster analysis.

In order to prove the presence or absence of the relationship between the General Travel Competitiveness Index and its sub-indexes, a correlation analysis is carried out (Fig. 1).

As can be seen from Fig. 1, the most common are the lines of General Travel Competitiveness and sub-indices of infrastructure and natural and cultural resources. The results of correlation calculations also confirm the existence of a direct relationship between these components (Table 1).

As can be seen from the data in Table 1, greatest impact on the Travel Competitiveness Index for EU countries have:

- infrastructure and its components (correlation coefficient is equal to 0.930235137 );

- natural and cultural resources (correlation coefficient is 0.891655781 ).

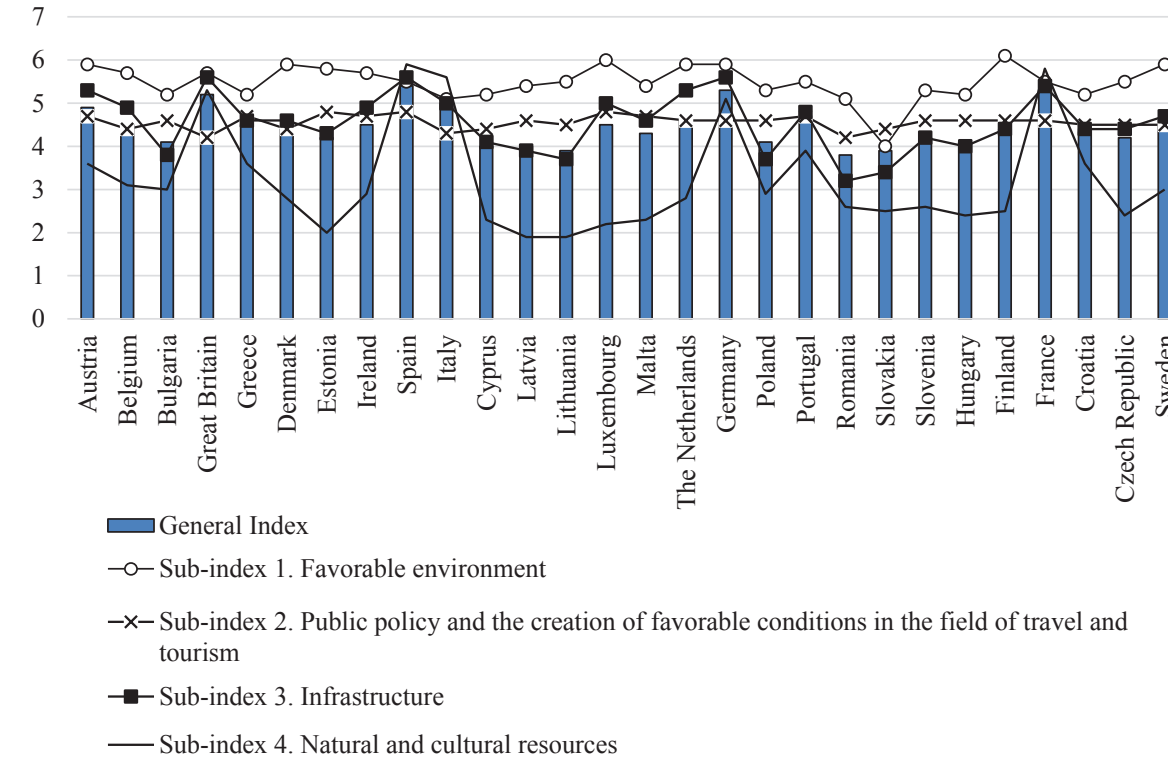

Fig. 1. The relationship between the Travel Competitiveness Index and its sub-indexes [11] 
The results of the correlation analysis between the Travel Competitiveness Index and its sub-indexes

\begin{tabular}{|l|l|}
\hline General Index - Sub-index 1 & 0.411007181 \\
\hline General Index - Sub-index 2 & 0.147844926 \\
\hline General Index - Sub-index 3 & 0.930235137 \\
\hline General Index - Sub-index 4 & 0.891655781 \\
\hline
\end{tabular}

Note: calculated by the author according to [11]

This concerns the favorable environment - its influence on the development of the tourism industry is almost absent (the correlation coefficient is 0.411007181 ). The state policy and its components in the context of the development of the European tourist space do not affect the competitiveness of countries in the field of travel and tourism (correlation coefficient is 0.147844926).

Since several countries are involved in the study and the need for analysis in many variables, hierarchical cluster analysis is used to order objects into relatively homogeneous groups.

Cluster analysis will provide an opportunity to develop a typology of countries in the region, grouping countries according to common features. For the analysis, data are selected for all 90 components of the 12 Travel Competitiveness Index of countries in the field of travel and tourism for 28 countries of the European Union.

The result of clustering is presented in the form of a dendrogram in Fig. 2.

The choice of the optimal number of clusters is determined on the basis of the analysis of special quality functionals, the possibilities of meaningful interpretation and other criteria. The researcher selects 7 clusters, for which, on the principle of similarity, it is advisable to single out the countries of the European Union by the level of their competitiveness (Table 2).

In order to characterize each of the selected clusters and to identify the commonality of countries within each of them, the $K$-means method in clusters is used as the most illustrative.

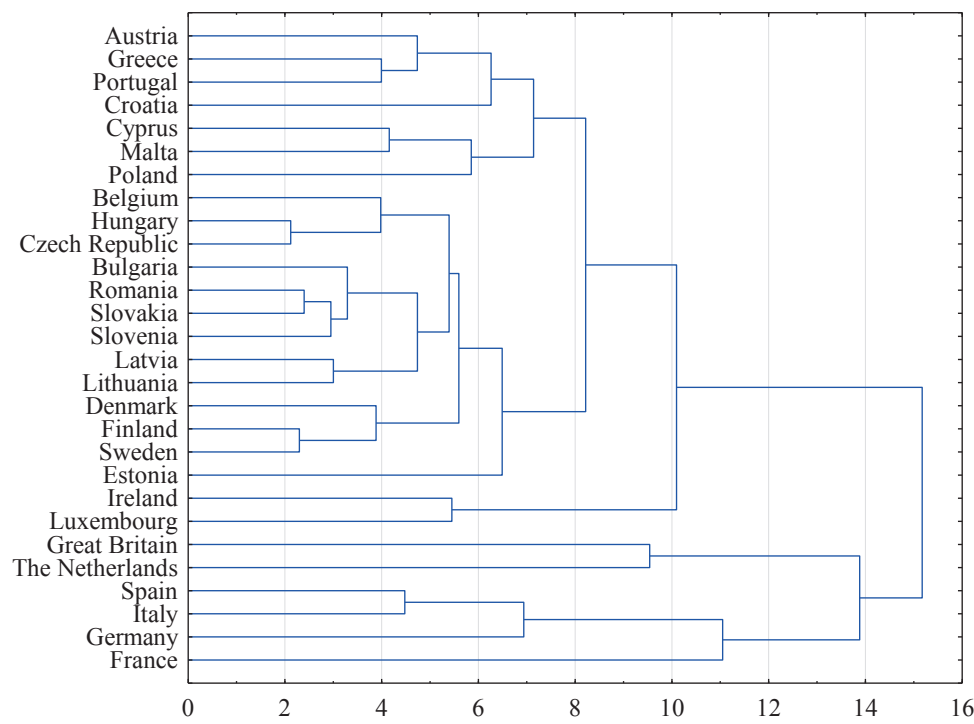

Fig. 2. Dendrogram of European Union countries for 90 components of the Travel Competitiveness Index [11]
The composition of clusters, selected by the Ward's method

\begin{tabular}{|c|c|l|}
\hline $\begin{array}{c}\text { No. of } \\
\text { cluster }\end{array}$ & $\begin{array}{c}\text { Number of objects in } \\
\text { the cluster }\end{array}$ & \multicolumn{1}{|c|}{ Cluster composition } \\
\hline Cluster 1 & 3 & Great Britain, Netherlands, France \\
\hline Cluster 2 & 3 & Spain, Italy, Germany \\
\hline Cluster 3 & 2 & Ireland, Luxembourg \\
\hline Cluster 4 & 6 & $\begin{array}{l}\text { Austria, Greece, Denmark, Portugal, } \\
\text { Finland, Sweden }\end{array}$ \\
\hline Cluster 5 & 2 & Cyprus, Malta \\
\hline Cluster 6 & 3 & Latvia, Lithuania \\
\hline Cluster 7 & 9 & $\begin{array}{l}\text { Belgium, Bulgaria, Poland, Romania, } \\
\text { 5lovakia, Slovenia, Hungary, Croatia, } \\
\text { Czech Republic }\end{array}$ \\
\hline
\end{tabular}

The $K$-means method allows to determine that each of the clusters has a different level of development of competitiveness of countries in the field of travel and tourism.

Fig. 3 shows the hierarchy of clusters according to the degree of development of the tourism industry.

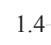

Fig. 3. The hierarchy of selected clusters by the level of development of the tourism industry

As can be seen from Fig. 3, the average value is equal to 1.034305 , which exceeds only two clusters -1 and 2 . In general, it can be stated that the difference between clusters 1-2 and 6-7 is insignificant. This allows to state a significant degree of similarity of characteristics between countries located in these clusters.

For greater clarity, let's analyze the average values of each cluster by sub-indexes, which will allow a more detailed study of which clusters have advantages in the development of infrastructure, availability of resources, favorable environment, and the like.

Fig. 4 shows the distribution of clusters by the average values of each of the sub-indexes. Thus, it is possible to conclude that, in terms of the environment's favorableness, all the clusters and, consequently, the EU countries have the same positions. In terms of public policy development and the creation of favorable conditions in the field of travel and tourism, clusters also have almost the same conditions, with the exception of negligible priority in the countries of cluster 1 
(Great Britain, Netherlands, France). In terms of infrastructure development, countries of 1-3 clusters have an advantage, that is, the most developed countries in the EU are United Kingdom, Netherlands, France, Spain, Italy, Ireland, Luxembourg.

However, the greatest diversity in clusters is inherent in the natural component of the development of tourism infrastructure, respectively, to the data in Fig. 4 countries of the cluster 2 have the greatest value of this sub-index - Spain, Italy, Germany, least of all - countries of the clusters 3-6 - Ireland, Luxembourg, Cyprus, Malta, Estonia, Latvia, Lithuania.

As for the hierarchy of sub-indexes for each of the clusters in Fig. 5 it is clearly seen that in the process of segmentation of the EU countries by the level of development of the tourism industry the resource component and, accordingly, the «Natural and cultural resources» sub-index have the greatest value.

The «Public policy and the creation of favorable conditions in the field of travel and tourism» and «Infrastructure» sub-indices have about the same significance for the segmentation of the EU countries by the level of development of the tourism industry. The smallest value in the segmentation processes is occupied by the favorable environment sub-index.

However, for the formation of tourism policy it is necessary to highlight the factors influencing the development of the tourist product.

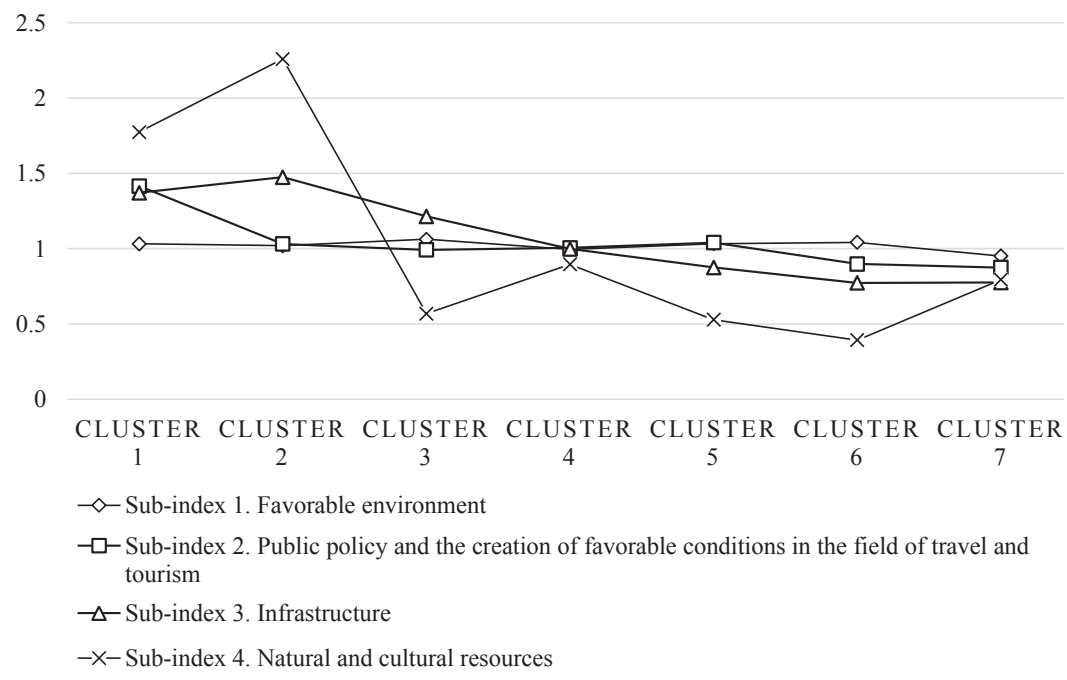

Fig. 4. Graph of average values of signs in clusters obtained by the Ward's method
To this end, it is proposed to use a factor analysis, which is a multidimensional method of research and is used to study the relationship between the values of variables. The main results of factor analysis are expressed in factor loads, factor fields, factor weights, eigenvalues of factors.

So, the conducted factor analysis allows the author to determine the factors on the development of the European tourist space in the context of the selected clusters and to determine the percentage of influence of each sub-index on the cluster countries. Table 3 and Fig. 6 shows the data according to which it can be concluded that the environment is significant for such countries as Austria, Greece, Denmark, Portugal, Finland, Sweden, Estonia, Latvia, and Lithuania. The development of public policy and the creation of favorable conditions in the field of travel and tourism are especially important for countries such as Austria, Greece, Denmark, Portugal, Finland, Sweden, United Kingdom, Netherlands, and France. Infrastructure development is a significant factor in the development of all countries of the European tourist space, however, it has the greatest influence for such countries as United Kingdom, Netherlands, France, Spain, Italy, Germany, Spain, Italy, Cyprus, Malta. The resource component of the development of the tourism industry most influences the development of the tourism industry in such countries as Spain, Italy, Germany, Ireland, Luxembourg.

Tahle 3

The distribution of clusters according to the degree of influence of the sub-indices of tourism and travel development

\begin{tabular}{|l|c|c|c|c|c|c|c|}
\hline \multicolumn{1}{|c|}{ Sub-indices } & Cluster 1 & Cluster 2 & Cluster 3 & Cluster 4 & Cluster 5 & Cluster 6 & Cluster 7 \\
\hline Sub-index 1. Favorable environment & 14 & 18.75 & 13.5 & 33 & 23 & 34 & 21 \\
\hline $\begin{array}{l}\text { Sub-index 2. Public policy and the creation of favorable } \\
\text { conditions in the field of travel and tourism }\end{array}$ & 20 & 6.25 & 13.5 & 25 & 17 & 6 & 15 \\
\hline Sub-index 3. Infrastructure & 33 & 31.25 & 33 & 22 & 30 & 20 & 27 \\
\hline Sub-index 4. Natural and cultural resources & 33 & 43.75 & 40 & 20 & 30 & 40 & 37 \\
\hline
\end{tabular}




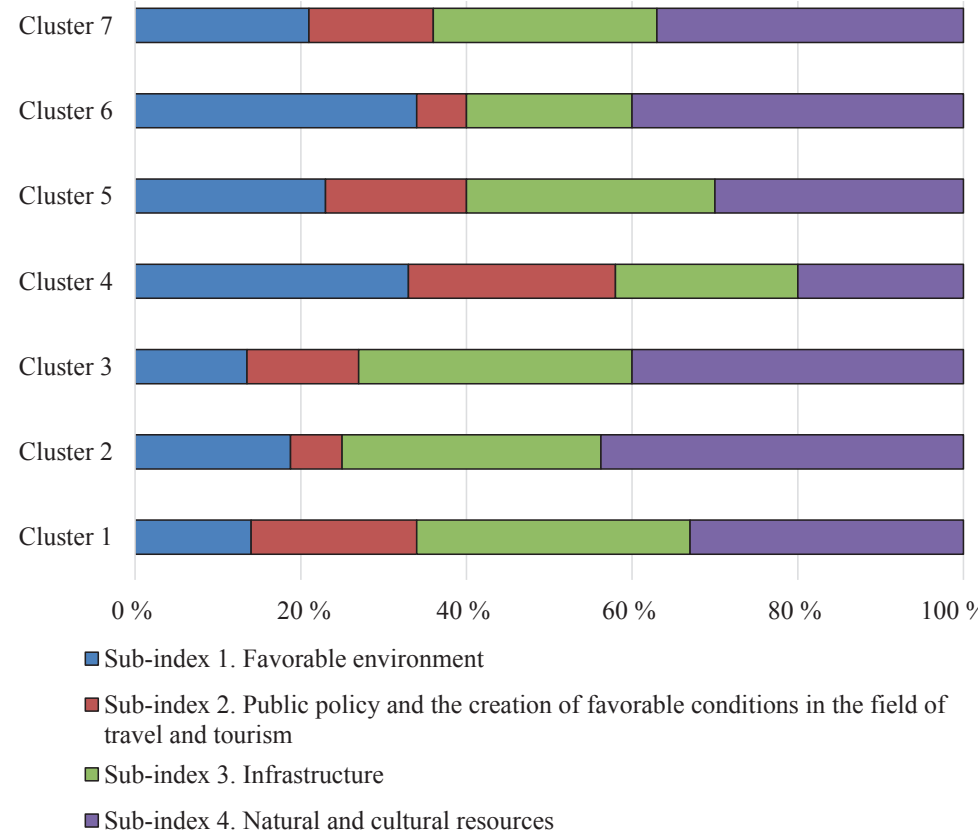

Fig. 6. Priority in development of the main components of the travel and tourism industry for all clusters of the European tourist space

Thus, it is possible to conclude that despite the fact that the countries of the European tourist space have some differences. The greatest influence on the development of the tourism industry has a resource component, the second most important is the degree of infrastructure development, the third place is occupied by the overall favorable environment. Government policy and the creation of favorable conditions in the field of travel and tourism have only $15 \%$ of the influence (Fig. 7).

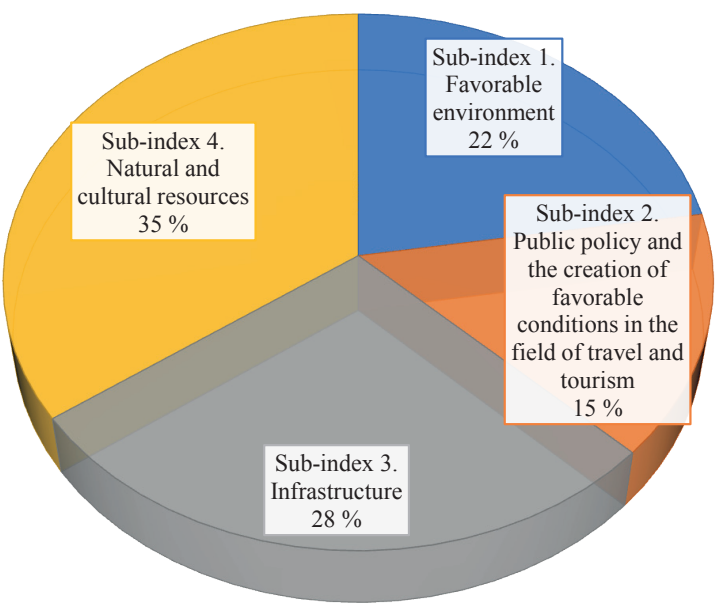

Fig. 7. Priority of development of the main components of the travel industry and tourism in the European tourist space

So, the segmentation of the European tourist space is carried out, which allows to determine not only groups of countries by the level of development of the tourism industry, but also to identify the most influential factors of its development for each of the groups. The results of the segmentation will make it possible to develop an appropriate tourism policy for the development of the European tourist space, taking into account all regional specificities.

\section{SWOT analysis of research results}

Strengths. A comprehensive multifactorial study of the competitive tourist space of the EU countries is carried out, which allows to segment the EU countries by the level of development of the tourism industry and to identify the main factors of its growth.

Weaknesses. The study is carried out according to the 2017 Travel Competitiveness Index, which does not allow to assess the dynamics of changes in the factors influencing the development of the EU tourism industry.

Opportunities. The results of the study can be used for the segmentation of another tourist region (for example, American).

Also, given the integration aspirations of Ukraine, it is interesting to apply the principles of shaping the tourism policy of some European countries, for example, Poland, under the conditions of Ukraine.

Threats. Outside the study are such important indicators of the functioning of the tourism industry, such as:

- share of tourism in the country's GDP;

- government costs on industry development;

- and so on, due to the lack of these indicators among the components of the Travel Competitiveness Index.

\section{Conclusions}

1. The segmentation of the European space is carried out according to the level of development of the tourism industry with the help of the cluster model and it is proved that there is a direct effect on the Travel Competitiveness Index, tourism resources and its components. Seven clusters of EU countries are distinguished by the level of development of the tourism industry:

1 - countries of high level of development of the tourism industry:

- cluster 1 (UK, Netherlands, France);

- cluster 2 (Spain, Italy, Germany).

2 - countries of the middle level of development of the tourism industry:

- cluster 3 (Ireland, Luxembourg);

- cluster 4 (Austria, Greece, Denmark, Portugal, Fin-

land, Sweden);

- cluster 5 (Cyprus, Malta);

- cluster 6 (Latvia, Lithuania);

- cluster 7 (Belgium, Bulgaria, Poland, Romania, Slovakia, Slovenia, Hungary, Croatia, Czech Republic).

It is concluded that the greatest importance in the process of segmentation of the EU countries in terms of the development of the tourism industry has a resource component and, accordingly, the «Natural and cultural resources» sub-index. The «Public policy and the creation of favorable conditions in the field of travel and tourism» and «Infrastructure» subindices have about the same significance for the segmentation of the EU countries by the level of development of the tourism industry. The smallest value in the segmentation process is occupied by the «Favorable environment» sub-index.

2. A factor analysis is carried out to determine significant factors in the development of the tourism industry 
for each segment (cluster) to further form the main aspects of tourism policy. The conclusion is made about the significant weight of the favorable environment for such countries as Austria, Greece, Denmark, Portugal, Finland, Sweden, Estonia, Latvia, and Lithuania. The development of public policy and the creation of favorable conditions in the field of travel and tourism are especially important for countries such as Austria, Greece, Denmark, Portugal, Finland, Sweden, United Kingdom, Netherlands, and France. Infrastructure development is a significant factor in the development of all countries of the European tourist space, however, it has the greatest influence for such countries as United Kingdom, Netherlands, France, Spain, Italy, Germany, Spain, Italy, Cyprus, Malta. The resource component of the development of the tourism industry most influences the development of the tourism industry in such countries as Spain, Italy, Germany, Ireland, Luxembourg.

\section{References}

1. Turystychna polityka zarubizhnykh krain: textbook / ed. by Parfinenko A. Yu. Kharkiv, 2015. 220 p.

2. Geografiya turizma: textbook / ed. by Aleksandrova A. Yu. Moscow, 2016. 592 p.

3. Causevic S., Lynch P. Political (in)stability and its influence on tourism development // Tourism Management. 2013. Vol. 34 P. 145-157. doi: http://doi.org/10.1016/j.tourman.2012.04.006

4. Kokkranikal J., Cronje P., Butler R. Tourism Policy and Destination Marketing in Developing Countries: The Chain of Influence Tourism Planning \& Development. 2011. Vol. 8, Issue 4. P. 359-380. doi: http://doi.org/10.1080/21568316.2011.603885
5. Guslev A. Sustainable Tourism Industry in the Context of Globalization // The Advanced Science Journal. 2015. Vol. 2015, Issue 2. P. 23-26. doi: http://doi.org/10.15550/asj.2015.02.023

6. Lee T. H. Influence analysis of community resident support for sustainable tourism development // Tourism Management. 2013 Vol. 34. P. 37-46. doi: http://doi.org/10.1016/j.tourman.2012.03.007

7. Spencer R. Development Tourism in Cuba: Experiential Learning and Solidarity in the Development Tourism Encounter // Tourism Planning \& Development. 2017. Vol. 15, Issue 3 P. 277-292. doi: http://doi.org/10.1080/21568316.2017.1403371

8. Markandya A. Economic Instruments for Sustainable Tourism Development // Tourism and Sustainable Economic Development. Boston: Springer, 2000. P. 145-157. doi: http://doi.org/ 10.1007/978-1-4615-4321-3 7

9. Sedarati P., Santos S., Pintassilgo P. System Dynamics in Tourism Planning and Development // Tourism Planning \& Development, 2018. P. 1-25. doi: http://doi.org/10.1080/21568316.2018.1436586

10. Khanova O. V. Bahatomirna otsinka vplyvu chynnykiv konkurentospromozhnosti turyzmu (na prykladi krain Yevropeiskoho rehionu) // Visnyk Kharkivskoho natsionalnoho universytetu imeni V. N. Karazina. Seriia «Mizhnarodni vidnosyny. Ekonomika. Krainoznavstvo. Turyzm». 2014. Vol. 1086, Issue 2. P. 188-191.

11. Travel \& Tourism Competitiveness Report 2015. URL: http:// reports.weforum.org/travel-and-tourism-competitiveness-report-2015/downloads (Last accessed: 20.04.2018)

Sklyarenko Yaroslava, Assistant, Department of Foreign Economic Relations, V. N. Karazin Kharkiv National University, Ukraine, e-mail: elenkaolenka@gmail.com, ORCID: http://orcid.org/00000003-2634-8542

Khanova Elena, PhD, Associated Professor, Department of Foreign Economic Relations, V. N. Karazin Kharkiv National University, Ukraine, e-mail: khanovaelena@ukr.net, ORCID: http://orcid.org/ 0000-0002-0681-4860 